Role of agricultural engineering in environmental and sustainable development

for the valley and delta areas: 1212 - 1227

\title{
EFFECT OF IRRIGATION SYSTEMS ON LETTUCE CROP
}

\section{EL-SHARKAWEY.A.F and M.Y.BONDOK}

\section{ABSTRACT}

Field experiment were executed at Gemmiza Agricultural Research Station during season 2009 /2010, to study effect of irrigation systems, drip (surface and subsurface) irrigation and traditional irrigation. Levels of nitrogen fertilizer inputs and row width on lettuce fresh weight (gm), lettuce fresh tall $(\mathrm{cm})$, The objectives of study are evaluation trickle irrigation systems on lettuce crop. Surface drip (DI), subsurface drip irrigation(SDI) compared with surface irrigation ( SI) and the interactions of water and nitrogen fertilizer inputs on crop yield and quality

The effect of irrigation systems, the results indicated that increase the lettuce fresh weight $(\mathrm{gm})$, lettuce fresh tall (cm), number of fresh leaf, lettuce stem weight $(\mathrm{gm})$ and lettuce stem tall $(\mathrm{cm})$. By using subsurface irrigation (SDI ) by 5,42\%; $28.43 \% ; 5.77 \% ; 15.73 \% ; 13.20 \% ; 33.72$ $\% ; 13,03 ; 14.39 \%$ and $33.62 \%$ compared with surface drip (DI )and surface irrigation ( (SI) systems resp.

The highest values were on double row under subsurface drip irrigation, the values were 570.01; 33.60; 49.00; 260.95 and 15.01 resp.

The data revealed that, the highest values of lettuce fresh weight (gm), lettuce fresh tall $(\mathrm{cm})$, number of fresh leaf, lettuce stem weight ( $\mathrm{gm})$ and lettuce stem tall $(\mathrm{cm})$. under double row and by using $45 \mathrm{u} \mathrm{N/fed}$., the values were $709.92 ;, 34.70$; 51.07; 283.78 and 16,17 resp.

The highest values of crops and field water use efficiency $(2271.58 \mathrm{~kg}$ and $2.40 \mathrm{~kg} / \mathrm{m}^{3}$ ) were obtained under subsurface trickle irrigation system. While the modified furrow irrigation system treatment induced the lowest values $\left(1768.75 \mathrm{~kg}\right.$ and $\left.1.31 \mathrm{~kg} / \mathrm{m}^{3}\right)$.

\footnotetext{
*Senior Rese. Agric. Eng. Res. Inst, Agric. Center, Egypt. ** Rese. Agric. Eng. Res. Inst, Agric. Center, Egypt.
} 


\section{INTRODUCTION}

The water requirement of a given crop is represented by its
evapotranspiration (ETc), basically defined as the rate of transfer
of water vapor from plant and soil surfaces to atmosphere. This is a key element for the implementation of irrigation management strategies for crop production at both farm and irrigation scheme levels and for the study of leaching of agrochemicals towards ground waters. In the agricultural areas of Arizona, irrigation plays an essential role in the production of grains, cotton, fruits, alfalfa, and vegetables (Irrigation Journal, 2001) Barber and Raine ( 2002) .reported that Soil-water availability is a major determinant of crop yield and is often highly correlated with the uniformity of irrigation application. Uneven watering has been found to affect crop growth for a range of crops including cauliflower and lettuce Fox et al. (1992) incorporated the lettuce water use data from Erie et al. (1965) into the AZSCHED (AriZona SCHEDuling) irrigation program. The estimates of head lettuce ET obtained by Erie et al. (1965) were based on gravimetric measurements of soil water content in furrow-irrigated lettuce fields. They concluded that the crop seasonal water use was about $216 \mathrm{~mm}$ for a three and a half month growing season with time of planting around September 15. The peak water use was observed to occur in the head development stage and they also showed that $56 \%$ of seasonal soil moisture depletion by crop water use occurred in the top $30 \mathrm{~cm}$. More recently.

Gallardo et al. (1996) and Grattan et al. (1998) reported that, Surface irrigation is still the most widely used method for irrigating lettuce in the US. But pressurized irrigation systems like sprinkler and subsurface drip have gained a lot of importance due to their ability to achieve higher irrigation efficiency and uniformity when compared to traditional surface systems. Considering the facts related to the importance of the drip irrigation systems for crop production in arid and semi-arid areas and the lack of more updated information on lettuce water use in Arizona grown under that irrigation method, a field study was conducted to determine the seasonal water use of subsurface-drip irrigated lettuce and to derive crop coefficients to be used in irrigation scheduling programs. 
(Titley 2000). This paper considers if modifications to SDI can improve the establishment of lettuce which SDI depends on capillary water movement from buried emitter to seedlings, evaporation, soil texture, structure and hydraulic conductivity of soil. Bed shape, number of tapes per bed and tape depth can also be important when establishing with SDI . Nassar and Aou ElAzem (2006) concluded that the subsurface trickle system treatment had singnicantly favored total fresh yield comparing with trickle and modified furrow treatments. The total fresh yields were 1660.0 , 1260 .0and $930.0 \mathrm{~kg} / \mathrm{fed}$. with irrigation by subsurface trickle ,surface trickle and modified furrow irrigation systems treatments resp.

Also ,the subsurface treatment exhibited sufficient available water in the soil layers, where the plants consumed most of water demand as well as surface trickle treatment ,followed by modified furrow treatment .Moreover, the highest water application efficiency $92.67 \%$ was recorded by subsurface trickle irrigation system treatment .Also, this treatment gave the highest water application efficiency .

Phone et al. (1993) reported that many commercial crops irrigated by subsurface trickle include tomato ,potato cantaloupe ,strawberry, lettuce ,cotton, sugarcane ,grapes, hips ,apple . They also demonstrated hat the subsurface trickle maximized water use efficiency and yield of these crops ,reduced evaporation at the soil surface and maintained constant soil water and cased upward hydraulic to minimize deep percolation and NO3 N leaching .

Ghali and Svehlik (1988).Plants responded to both increased crop factor (CF), that is increased irrigation amount, and irrigation frequency (IF). However, for every combination of CF and IF, the growth of plants with modified SDI was greater than with conventional SDI. To maintain an optimal soil water regime on sandy soils, short, frequent pulses of water were required More frequent water application through SDI. Was also better in work reported by El-Gindy and El-Araby (1996) and Silber et al. (2003). Whilst the present results agree with the earlier findings on 'pulse irrigation', also showed that with a modified SDI either fewer pulses, or less irrigation water, may be used to achieve a similar results. Further work is needed to quantify this and develop management guidelines. 
Thomas et al (2002) Maximum marketable broccoli yields occurred at $\mathrm{N}$ rates of 300 to $500 \mathrm{~kg} \mathrm{ha}^{-1}$. There were no SWT $\mathrm{x} \mathrm{N}$ interactions for marketable yield, and very $\mathrm{f}$

Stivers et al. (1993) reported that Western broccoli growers may apply as much as $400 \mathrm{~kg} \mathrm{~N} \mathrm{ha}^{-1}$. Other researchers have noted a positive broccoli yield response to $\mathrm{N}$ rates

El Farrah (2001) showed that sorghum growth increased under subsurface drip line compared with surface drip line irrigation. Spinach gave a similar trend of enhanced growth with optimum drip line depth of $20 \mathrm{~cm}$.

Lamm ,et al . (1995) repotted that, careful management of subsurface drip irrigation systems reduced net irrigation needs by nearly $25 \%$ while still maintaining top yields of 12-15 t / ha. Soil type drip line installation depth, crop type and reliability and amount of in- season precipitation are the major factors which determine the maximum spacing.

\section{MATERIALS AND METHOD}

The field experiments were performed at Gemmeza Agricultural Research Station Farm (Gharbeia Government) inseason2009-2010(4mouths)to study the effect of the irrigation systems (surface ;subsurface drip compared with furrow irrigation) ; width of row (60 and $120 \mathrm{~cm}$ with planted on each side) ; nitrogen rates on amount of irrigation water ; water use efficiency and yield of lettuce. The soil of the experiment site is clayey in texture and particle size distribution and some of soil water constants are shown in Table (1)

Table (1) :Mechanical analysis and some soil moisture contents of the studied soil experimental.

\begin{tabular}{|c|c|c|c|c|c|c|c|}
\hline $\begin{array}{c}\text { Depth } \\
\mathrm{cm}\end{array}$ & $\begin{array}{c}\text { Fine } \\
\text { sand } \%\end{array}$ & $\begin{array}{l}\text { Coarse } \\
\text { sand } \%\end{array}$ & Silt $\%$ & Clay\% & $\begin{array}{c}\text { Soil } \\
\text { texture }\end{array}$ & F C. $\%$ & W.P.\% \\
\hline $0-15$ & 3.7 & 20.3 & 26.3 & 49.7 & Clay & 42.50 & 21.10 \\
\hline $15-30$ & 3.6 & 20.55 & 27.30 & 48.45 & Clay & 42.90 & 20.70 \\
\hline $30-45$ & 3.65 & 20.55 & 28.25 & 47.55 & Clay & 43.60 & 21.90 \\
\hline $45-60$ & 4.25 & 20.75 & 28.45 & 46.55 & Clay & 44.00 & 22.30 \\
\hline
\end{tabular}

The transplanting date of lettuce seedlings were 21 of December 2009, by using surface irrigation, transplanting at $25 \mathrm{~cm}$ between seedlings, the 
area of experiment $120 \times 18 \mathrm{~m}$ divided to three replicates each one $40 \mathrm{x}$ $18 \mathrm{~m}$, the distance between lateral $60 \mathrm{~cm}$ and its long $18 \mathrm{~m}$. surface(DI); subsurface drip irrigation (SDI) put at depth $15 \mathrm{~cm}$, both drip types used $2 \mathrm{~L} / \mathrm{h}$ emitters at $50 \mathrm{~cm}$ spacing as shown in fig. ( 1 ) .

Fig. ( 1 ) illustrated layout of experimental field of lettuce .
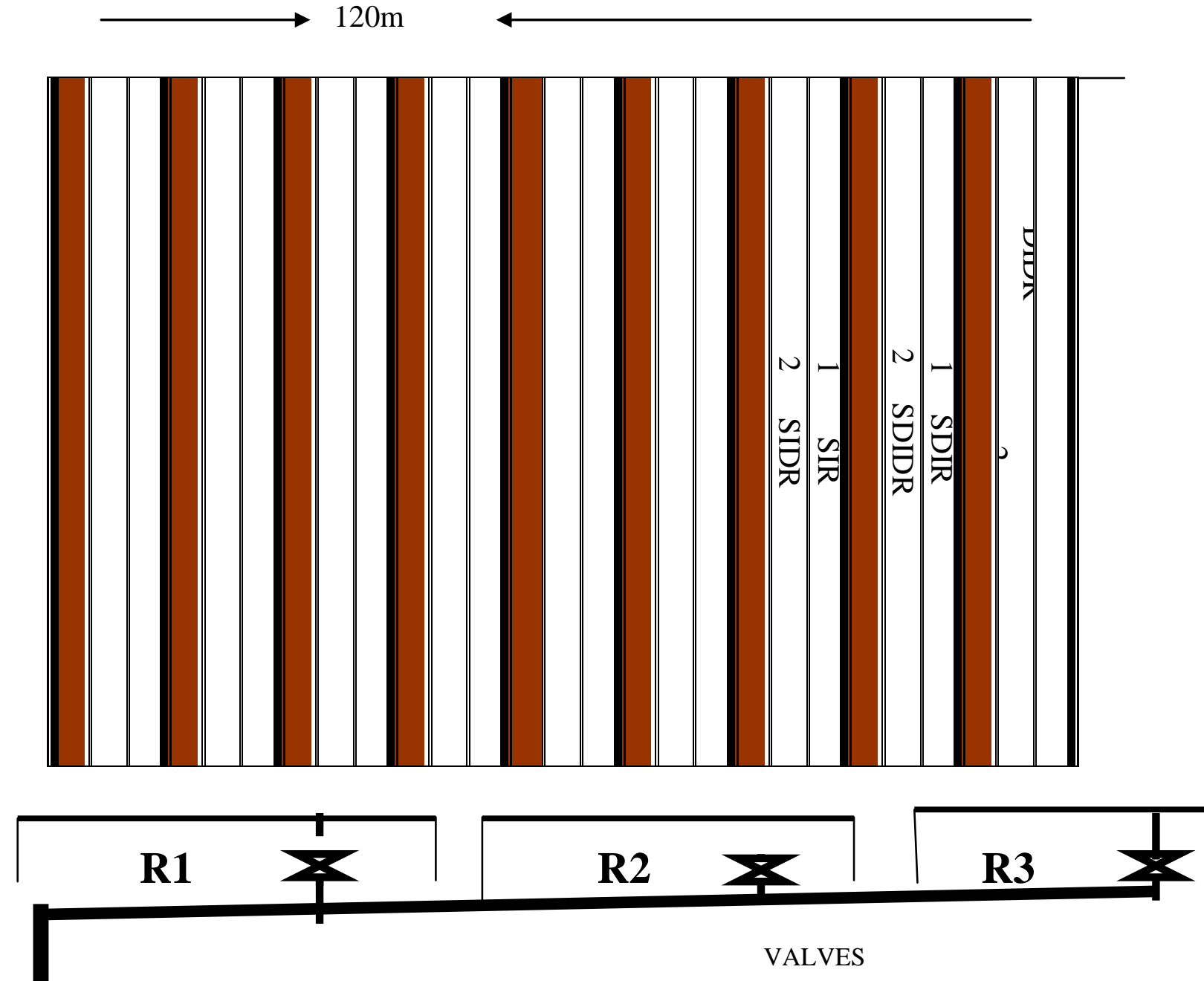

SUPMAIN LINE

E LIN MAIN

CONTROLHEAD

$1=0.6 m-2=1,2 m$

Electromotor

Fig. (1):Layout of experimental field of lettuce $(120 \mathrm{~m} \times 20 \mathrm{~m})$ 
General agronomic management ensured conditions were favorable to plant growth.

Were controlled before field preparations by spraying HarbaZ $48 \%$

( $1 \mathrm{~L} / \mathrm{fed}$ ) ); weeds Fertilizers were ten days after transplanting The adopted treatments were arranged in split split - plot experimental design with 3 replicates as follows.

Main - plot (irrigation system )

1 - subsurface drip irrigation (SDI )

2 - Surface drip irrigation (DI)

3 - Surface irrigation ( SI )

Sub main - plot ( width of row )

1 - width of row $60 \mathrm{~cm}$ with transplanting at mid row ( R )

2- Width of row $120 \mathrm{~cm}$ with transplanting on each side ( Dr )

\section{Sub -sub main -plot (nitrogen rates )}

1 - fertilizer by $15 \mathrm{u} \mathrm{N} /$ fed .

2 - fertilizer by $30 \mathrm{u} \mathrm{N} / \mathrm{fed}$.

3- fertilizer by $45 \mathrm{u} \mathrm{N} / \mathrm{fed}$.

At harvest in March 2010 average fresh weigh $(\mathrm{gm})$, fresh tall $(\mathrm{cm})$ ,number of leave,stem weigh ( $\mathrm{gm}$ )and stem tall $(\mathrm{cm})$ of area $\mathrm{m}^{2}$

\section{1 -Irrigation water calculations:}

\section{1. 1- Furrow irrigation}

The irrigation water was supplied through a circular orifice of $10 \mathrm{~cm}$ diameter and its discharge rate was calculated by using the equation of James (1988) as follows:

$\mathrm{Q}=0.61 \mathrm{KAH}^{1 / 2}$

Where,

$\mathrm{Q}=$ orifice discharge $(1 / \mathrm{s})$

$\mathrm{A}=$ the area of orifice opening $\left(\mathrm{cm}^{2}\right)$

$\mathrm{H}=$ head, (m)

$\mathrm{K}=$ unit constant. $\left(\mathrm{K}=0.443\right.$ for $\mathrm{Q}$ in $\mathrm{l} / \mathrm{s}$, $\mathrm{A}$ in $\mathrm{cm}^{2}$, and $\mathrm{H}$ in $\left.\mathrm{m}\right)$

\section{2 .drip irrigation.}

* Pan evaporation management.

Reference evapotranspiration (ETo) was calculated according to (Doorenbos and Prutt (1977): as follow: 
$\mathrm{ETo}=\mathrm{Kp} \times$ Epan

Where :

ETo $=$ reference evapotranspiration $(\mathrm{mm} /$ day $)$

$\mathrm{Kp}=$ pan coefficient

Epan $=$ pan evaporation $(\mathrm{mm})$

Eta crop $=$ ETo $\mathrm{x} k \mathrm{kc}$

Where:

ETa crop $=$ crop consumptive use $(\mathrm{mm} /$ day).

$\mathrm{Kc}=$ crop coefficient, (dimension less).

The agro climatology data for Gambia Governorate ETo $\mathrm{mm} /$ day , Kc of lettuce and ETa mm / day, as shown in table (2 ).

Table (2): values for Kc , Eto and Eta $\mathrm{mm} /$ day for the location of Kator .

\begin{tabular}{|l|l|l|l|l|l|l|l|l|}
\hline Months. & Jan. & Feb. & Mar. & Apr. & May. & Jun. & Jul. & Aug. \\
\hline Kc & 0.75 & 1.0 & 0.95 & & & & & \\
\hline Eto. & 1.54 & 2.39 & 3.52 & & & & & \\
\hline Eta & 1.25 & 3.6 & 4.28 & & & & & \\
\hline
\end{tabular}

\subsection{3- Leaching requirements}

Leaching requirement (LR) estimated according to (Doorenbos and pruit,1977) by the following equation.

$\mathrm{ECw}$
$\mathrm{LR}=$
Max ECe - ECw

where:

$\mathrm{ECW}=$ electrical conductivity of irrigation water, $\mathrm{dS} / \mathrm{m}$.

$\mathrm{ECe}=$ electrical conductivity of the soil saturation extract $\mathrm{dS} / \mathrm{m}$.

Max $\mathrm{ECe}=$ maximum tolerable electrical conductivity of the soil saturation extract.

$$
\text { D } \quad X \quad A
$$

$\mathrm{QS}=$

\section{H X EA}

Where:

$\mathrm{QS}=$ is the supply rate in $1 / \mathrm{h}$

$\mathrm{D}=$ depth rate irrigation water requirement in $\mathrm{mm} /$ day

$\mathrm{A}=$ area being irrigated in $\mathrm{m}^{2}$.

$\mathrm{H}=$ net irrigation operational time in $\mathrm{h} /$ day 
$\mathrm{Ea}=$ application efficiency.

\subsection{Fresh Yield:}

Lettuce fresh wt. (kg), calculated the yield per Fadden.

\section{2.1 Water use efficiency (WUE)}

was calculated by dividing the yield by the total applied water according to the equation of Vitas (1965) as follows.

$$
\mathrm{WUE}=\frac{\mathrm{Cy}}{\mathrm{AW}} \quad \mathbf{6}
$$

Where:

WUE $=$ water use efficiency $\mathrm{kg} / \mathrm{m}^{3}$

$\mathrm{Cy}=$ the Lettuce fresh wt. $(\mathrm{kg})$.

Aw $=$ the amount of the applied water $\mathrm{m}^{3} /$ fad.

Actual water consumptive use (Et actual) was calculated according to Bondok computer program., data in table (3) shown input data of pan evaporation under drip irrigation system .

\section{Table (3 ): input data of pan evaporation management under drip} irrigation system (data Jan.)

\begin{tabular}{|c|l|c|}
\hline No & \multicolumn{1}{|c|}{ Site } & Gemezza station. \\
\hline 1 & Crop name. & Lettuce. \\
\hline 2 & Soil type. & Clay. \\
\hline 3 & Growth period. & 21dec to 20 mr \\
\hline 4 & Evaporation pan (Epan) mm/day. & - \\
\hline 5 & Pan coefficient (KP). & 1.54 \\
\hline 6 & Reference evaporation (ETo) mm/day. & 0.75 \\
\hline 7 & Crop Coefficient (KC) dimension less. & 0.85 \\
\hline 8 & Coefficient of reduction (KR) \%. & 0.38 \\
\hline 9 & $\begin{array}{l}\text { Electrical conductivity of irrigation water } \\
\text { (Ecw) ds/m }\end{array}$ & 0.66 \\
\hline 10 & $\begin{array}{l}\text { Maximum electrical conductivity extract (Ece) } \\
\text { ds/m. }\end{array}$ & 0.3 \\
\hline 11 & Irrigation area (IA) m2. & 2 \\
\hline 12 & Emitter discharge (EQ) $1 / \mathrm{h}$ & 90 \\
\hline 13 & System efficiency (SE) \%. & \\
\hline
\end{tabular}


Data in table ( 4 ) shown that, out put data of pan evaporation under drip irrigation system

Table (4): out put data of pan evaporation management under drip irrigation system (data jan )

\begin{tabular}{|c|l|c|}
\hline 14 & Site & Gemezza station \\
\hline 15 & Crop . & Lettuce. \\
\hline 16 & $\begin{array}{l}\text { Actual evapotranspiration per day (Eta) } \\
\text { mm/day. }\end{array}$ & 0.98 \\
\hline 17 & Net leaching requirement (LR)\% & 0.28 \\
\hline 18 & $\begin{array}{l}\text { Actual evapotranspiration+ Net leaching } \\
\text { (requirements)(Rc) mm/day. }\end{array}$ & 1.25 \\
\hline 19 & Net time (duration) (Tn) h/day. & 0.2 \\
\hline
\end{tabular}

Data in table ( 5 ) shown that, the irrigation duration daily $\mathrm{mm} /$ day of lettuce crop under trickle irrigation with average discharge of emitter $21 / \mathrm{h}$.

Table (5): Irrigation duration ( min. / day) of lettuce under trickle irrigation .

\begin{tabular}{|c|c|c|c|c|c|}
\hline Crop & Growth Period & Jan. & Feb. & Mar. & $\begin{array}{l}\text { Average } \\
\text { discharge of } \\
\text { emitter } 1 / \mathrm{h}\end{array}$ \\
\hline lettuce & 21Dec-20Mar. & $12 \mathrm{~min} /$ day & $36 \mathrm{~min} /$ day & $43 \mathrm{~min} /$ day & 2.00 \\
\hline
\end{tabular}

\section{RESULTS AND DISCUSSION}

\section{Relation between irrigation systems and fertilizer on lettuce yield}

The differences in fresh weigh $(\mathrm{gm})$, fresh tall $(\mathrm{cm})$,number of leave ,stem weigh $(\mathrm{gm})$ and stem tall $(\mathrm{cm})$ and were substantial data in table ( 6 ),reveal that, with the subsurface drip irrigation ( SDI) recording increase of fresh weigh by $5.42 \%$ and $28.43 \%$ compared with Surface drip irrigation (DI) and Surface irrigation ( SI ) resp. ,also found increasing in lettuce stem tall by $5.77 \%$ and $15.73 \%$ compared with DI and SI irrigation systems resp.. the same trend fond with both number of leaves ,stem weigh and stem tall under SDI irrigation the increasing by $13.20 \%$ and $33.72 \%, 14.39 \%$ and $33.62 \%$ compared with DI and SI irrigation systems resp. 
Data in table (6) showed effect levels of fertilization under irrigation systems, the data showed that, increasing levels of fertilization from 15 , 30 and $45 \mathrm{u} \mathrm{N} / \mathrm{fed}$. lead to increase fresh weigh, fresh tall, number of leaves ,stem weigh, stem tall and under all irrigation systems .The highest increase of fertilization with $45 \mathrm{u} \mathrm{N} /$ fed. under subsurface drip irrigation compared by drip irrigation and surface irrigation .

This result could be attributed to uniform distribution of sufficient available water, fertilizers directly in the root zone all time because the subsurface drip irrigation depends on capillary water movement from buried emitter to seedlings. The lowest values under furrow irrigation, this may be due to insufficient water to reach the root zone in particular early growth stage where a small root system could not extend enough to reach the water at least time for interval of irrigation.

Table (6 ): Relation between irrigation systems and fertilizer on lettuce yield:

\begin{tabular}{|c|c|c|c|c|c|c|}
\hline $\begin{array}{c}\text { Irrigation } \\
\text { Systems. }\end{array}$ & $\begin{array}{c}\text { Levels of } \\
\text { fert. .uN } \\
/ \text { fed }\end{array}$ & $\begin{array}{c}\text { Lettuce } \\
\text { fresh } \\
\text { wt. (gm) }\end{array}$ & $\begin{array}{c}\text { Lettuce } \\
\text { fresh. } \\
\text { Ta.(Cm.) }\end{array}$ & $\begin{array}{c}\text { Number } \\
\text { of leaves }\end{array}$ & $\begin{array}{c}\text { Lettuce } \\
\text { Stem } \\
\text { wt. (gm) }\end{array}$ & $\begin{array}{c}\text { Lettuce } \\
\text { stem } \\
\text { ta. (Cm.) }\end{array}$ \\
\hline SDI & $15 \mathrm{uN} / \mathrm{fed}$ & 365.00 & 28.22 & 34.29 & 167.22 & 10.24 \\
\hline & $30 \mathrm{uN} / \mathrm{fed}$ & 524.47 & 31.55 & 46.95 & 257.17 & 14.79 \\
\hline & $45 \mathrm{uN} / \mathrm{fed}$ & 733.07 & 36.47 & 53.55 & 334.82 & 17.27 \\
\hline $\mathrm{X}$ & & 540.85 & 32.08 & 44.93 & 253.07 & 14.15 \\
\hline $\mathrm{DI}$ & $15 \mathrm{uN} / \mathrm{fed}$ & 345.82 & 26.97 & 27.77 & 147.82 & 9.95 \\
\hline & $30 \mathrm{uN} / \mathrm{fed}$ & 483.84 & 30.62 & 41.72 & 230.55 & 12.22 \\
\hline $\mathrm{X}$ & $45 \mathrm{uN} / \mathrm{fed}$ & 713.2 & 33.42 & 49.57 & 293.32 & 14.94 \\
\hline SI & 1 & 514.29 & 30.43 & 39.69 & 223,90 & 12.37 \\
\hline & $30 \mathrm{uN} / \mathrm{fed}$ & 345.24 & 27.59 & 35.65 & 166.08 & 10.37 \\
\hline & $45 \mathrm{uN} / \mathrm{fed}$ & 626.67 & 31.70 & 40.71 & 205.35 & 13.92 \\
\hline $\mathrm{X}$ & & 421.13 & 27.72 & 33.60 & 161.40 & 10.59 \\
\hline
\end{tabular}

$\mathrm{X}$ : The average value. 


\section{Effect of both irrigation systems and width of row on lettuce yield.}

Data in table (7 ) illustrated that, the effect of both irrigation systems and width of row on lettuce fresh weight $(\mathrm{gm})$, lettuce fresh tall $(\mathrm{cm})$, number of fresh leaf, lettuce stem weight $(\mathrm{gm})$ and lettuce stem tall $(\mathrm{cm})$. Data showed that the highest values under subsurface drip irrigation ,the values were $540.85,32.08,46.59,253.07$ and 14.13for both lettuce fresh tall $(\mathrm{cm})$, number of fresh leaf, lettuce stem weight $(\mathrm{gm})$ and lettuce stem tall $(\mathrm{cm})$ resp. .Followed by the values under surface drip irrigation, the values were $514.24,30.33,39.68,207.23$ and 12.37 resp. The lowest values under furrow irrigation the values 421.13, 27.72, 33.59, 161.40 and 11.09 resp. . Data also showed that ,affected both lettuce fresh weight $(\mathrm{gm})$, lettuce fresh tall $(\mathrm{cm})$, number of fresh leaves, lettuce stem weight (gm) and lettuce stem tall $(\mathrm{cm})$.by row and double row under irrigation systems .The highest values were on double row under subsurface irrigation ,the values were 570.01, 33.60, 49.00, 260.95 and 15.01 resp. The values under double row higher than the values under row ,that may be return to double row leading to irregular distribution of moisture

Table ( 7 ) : Effect of irrigation systems and width of row on lettuce production

\begin{tabular}{|c|c|c|c|c|c|c|}
\hline $\begin{array}{c}\text { Irrigation } \\
\text { Systems. }\end{array}$ & $\begin{array}{c}\text { furrow } \\
\text { width }\end{array}$ & $\begin{array}{c}\text { Lettuce } \\
\text { fresh } \\
\text { wt. (g) }\end{array}$ & $\begin{array}{c}\text { Lettuce } \\
\text { fresh. } \\
\text { Ta.(Cm.) }\end{array}$ & $\begin{array}{c}\text { Number } \\
\text { of } \\
\text { leaves }\end{array}$ & $\begin{array}{c}\text { Lettuce } \\
\text { Stem } \\
\text { wt. (g) }\end{array}$ & $\begin{array}{c}\text { Lettuce } \\
\text { stem } \\
\text { ta. } \\
\text { (Cm.) }\end{array}$ \\
\hline SDI & Dr & 570.01 & 33.60 & 49.00 & 260.95 & 15.01 \\
\hline & $\mathrm{R}$ & 511.68 & 30.56 & 44.19 & 245.19 & 13.25 \\
\hline & $\mathrm{x}$ & 540.85 & 32.08 & 46.59 & 253.07 & 14.13 \\
\hline DI & $\mathrm{Dr}$ & 535.62 & 31.13 & 41.70 & 212.15 & 13.33 \\
\hline & $\mathrm{R}$ & 492.95 & 29.53 & 37.67 & 202.31 & 12.68 \\
\hline & $\mathrm{x}$ & 514.28 & 30.33 & 39.68 & 207.23 & 13.01 \\
\hline SI & $\mathrm{Dr}$ & 444.24 & 28.31 & 34.84 & 171.30 & 11.40 \\
\hline & $\mathrm{R}$ & 398.01 & 27.12 & 32.35 & 151.50 & 9.50 \\
\hline & $\mathrm{x}$ & 421.13 & 27.72 & 33.59 & 161.40 & 10.45 \\
\hline
\end{tabular}

R: row width $60 \mathrm{~cm}$; Dr; : row width $120 \mathrm{~cm}$.; x: : the average value 


\section{Effect of fertilization levels on lettuce yield}

Data in table (8)illustrated that, lettuce fresh weight (gm), lettuce fresh tall $(\mathrm{cm})$, number of fresh leaf, lettuce stem weight $(\mathrm{gm})$ and lettuce stem tall $(\mathrm{cm})$. affected by nitrogen fertilization levels. The data revealed that, when increasing nitrogen levels from $15-45 \mathrm{uN} / \mathrm{fed}$, ,lead to increase yield with row and double row. The highest values of , lettuce fresh weight $(\mathrm{gm})$, lettuce fresh tall $(\mathrm{cm})$, number of fresh leaf, lettuce stem weight $(\mathrm{gm})$ and lettuce stem tall $(\mathrm{cm})$ under $45 \mathrm{uN} / \mathrm{fed}$, the values were $690.98,33.86,49.44,277.80$ and 15.38 resp followed by the values under $30 \mathrm{uN} / \mathrm{fed}$, the values were $451.18,29.92,41.44,217.93$ and 12.40 resp. 'The latest values by using $15 \mathrm{~N} /$ fed . values were $334.10,26.35$, $28.83,142.60$ and $9.23 \mathrm{rsp}$. These results my be related to increase water consumptive when increase fertilizer and increasing the green yield. Also data showed that, when planted on double row lead to increasing yield compared by row with all fertilization levels, the highest values under double row and by using $45 \mathrm{u} \mathrm{N} /$ fed. Values were 709.92, 34.70, 51.07, 283.78 and 16,17 resp.. these results my be related to under subsurface drip irrigation the amount of water was little and buried emitter to seedlings, so the crop useful from all fertilizer .while under surface irrigation the amount of water was much, fertilizer drainage after root zoon and the crop unuesful from all fertilizer.

Table ( 8 ) : Effect of fertilization levels on lettuce yield

\begin{tabular}{|c|c|c|c|c|c|c|}
\hline $\begin{array}{c}\text { Fertilizatio } \\
\mathrm{n}\end{array}$ & $\begin{array}{c}\text { Furrow } \\
\text { width }\end{array}$ & $\begin{array}{c}\text { Lettuc } \\
\text { e fresh } \\
\text { wt. (g) }\end{array}$ & $\begin{array}{c}\text { Lettuce } \\
\text { fresh. } \\
\text { ta.(Cm) }\end{array}$ & $\begin{array}{c}\text { Number } \\
\text { of leave }\end{array}$ & $\begin{array}{c}\text { Lettuce } \\
\text { Stem } \\
\text { wt. (g) }\end{array}$ & $\begin{array}{c}\text { Lettuce } \\
\text { stem } \\
\text { ta.(Cm) }\end{array}$ \\
\hline $15 \mathrm{u} \mathrm{N} /$ fed & D.r & 353.87 & 27.10 & 29.63 & 163.26 & 9.86 \\
\hline & R & 314.32 & 25.60 & 28.02 & 121.94 & 8.59 \\
\hline & X & 334.10 & 26.35 & 28.83 & 142.60 & 9.23 \\
\hline $30 \mathrm{uN} /$ fed & D.r & 486.08 & 31.24 & 44.84 & 230.69 & 14.00 \\
\hline & R & 416.26 & 28.59 & 38.08 & 205.18 & 10.80 \\
\hline & X & 451.18 & 29.92 & 41.44 & 217.93 & 12.40 \\
\hline 45. uN/fed & D.r & 709.92 & 34.70 & 51.07 & 283.78 & 16.17 \\
\hline & R & 672.03 & 33.02 & 47.81 & 271.82 & 14.58 \\
\hline & X & 690.98 & 33.86 & 49.44 & 277.80 & 15.38 \\
\hline
\end{tabular}




\section{Effect of row and double row on lettuce fresh yield}

Data in table (9) the general average of both row and double row under all irrigation systems to explain the effect of row width on lettuce yield. The values revealed that, the effected of row and double row on lettuce fresh weight $(\mathrm{gm})$, lettuce fresh tall $(\mathrm{cm})$, number of fresh leaf, lettuce stem weight $(\mathrm{gm})$ and lettuce stem tall $(\mathrm{cm})$, data in table showed that the double row lead to increase both lettuce fresh weight $(\mathrm{gm})$, lettuce fresh tall $(\mathrm{cm})$, number of fresh leaf, lettuce stem weight $(\mathrm{gm})$ and lettuce stem tall $(\mathrm{cm})$. Compared with row ,the percentage of increasing were 10.50, $6.67,9.93,13.14$ and $17.56 \%$ resp.

Table (9) : Effect of row and double row on lettuce fresh yield .

\begin{tabular}{|c|c|c|c|c|c|}
\hline $\begin{array}{c}\text { Furrow } \\
\text { Width. }\end{array}$ & $\begin{array}{c}\text { Lettuce } \\
\text { fresh } \\
\text { wt. (g) }\end{array}$ & $\begin{array}{c}\text { Lettuce } \\
\text { fresh. } \\
\text { ta.(Cm.) }\end{array}$ & $\begin{array}{c}\text { Number } \\
\text { of leave }\end{array}$ & $\begin{array}{c}\text { Lettuce } \\
\text { Stem } \\
\text { wt. (g) }\end{array}$ & $\begin{array}{c}\text { Lettuce } \\
\text { stem } \\
\text { ta. (Cm.) }\end{array}$ \\
\hline Dr & 774.94 & 46.52 & 62.77 & 338.86 & 20.07 \\
\hline R. & 701.32 & 43.61 & 57.10 & 299.50 & 17.07 \\
\hline
\end{tabular}

\section{Water use efficiency (WUE )}

Water use efficiency for crop affected by irrigation systems of lettuce crop the data showed that in table (10) higher values of crops and field water use efficiency $\left(2271.58 \mathrm{~kg}\right.$ and $\left.2.40 \mathrm{~kg} / / \mathrm{m}^{3}\right)$ ) were obtained under subsurface trickle irrigation system. While the modified furrow irrigation system treatment induced lower values $\left(1768.75 \mathrm{~kg}\right.$ and $\left.1.31 \mathrm{~kg} / \mathrm{m}^{3}\right)$.

The highest value return to divided yield $\mathrm{Kg}$ by the amount of the applied water $\mathrm{m}^{3} / \mathrm{fad}$.,the amount of water under drip irrigation was lower compared with surface irrigation

Table ( 10): Fresh yield, amount of irrigation water and water use efficiency

\begin{tabular}{|l|c|c|c|}
\hline Irrigation systems & SDI & DI & SI \\
\hline Lettuce fresh $\mathrm{kg} / \mathrm{fed}$ & 2271.58 & 2159.98 & 1768.75 \\
\hline Amount of water $\mathrm{m}^{3} / \mathrm{fed}$ & 945 & 945 & 1350 \\
\hline Water use efficiency $\mathrm{Kg} / \mathrm{m}^{3}$ & 2.40 & 2.29 & 1.31 \\
\hline
\end{tabular}




\section{SUMMARY AND CONCLUSIONS}

The main results in the present work can be summarized and concluded in the following points .

1-The highest values of lettuce fresh weight (gm ), lettuce fresh tall $(\mathrm{cm})$, number of leaves, lettuce stem weight $(\mathrm{gm})$ and lettuce stem tall $(\mathrm{cm})$ under subsurface drip irrigation the values were 540,85, $32,08,44,93,253,07$ and 14,15 resp.

2- -The highest values of lettuce fresh weight (gm ), lettuce fresh tall $(\mathrm{cm})$, number of leaves, lettuce stem weight $(\mathrm{gm})$ and lettuce stem tall $(\mathrm{cm})$.under fertilization level $45 \mathrm{u} \mathrm{N} / \mathrm{fed}$., the values were 690,98, $33,86,49,44,277,80$ and 15,38 resp.

3- Due to transplanting on double row with planted in each side , increasing lettuce fresh weight (gm ), lettuce fresh tall $(\mathrm{cm})$, number of leaves, lettuce stem weight $(\mathrm{gm})$ and lettuce stem tall $(\mathrm{cm})$, the values were 774,94 ,46,52, 62,77, 338,86 and 20,07 resp.

4- Water use efficiency was the highest value $2.40 \mathrm{~kg} / \mathrm{m}^{3}$ under subsurface drip irrigation.

\section{REFERENCES}

Barber, S.A. and Raine, S. R. (2002) Using commercial distribution uniformity and yield data to improve irrigation management. International Water \& Irrigation 22(4), 17-22.

El-Gindy A.M. and El-Araby A.M. (1996) Vegetable crop response to surface and subsurface drip under calcareous soil. Evaporation and irrigation scheduling. Proc. of the Inter. Conf. Nov. 3-6 San Antonio, Texas.

Erie, L.J.; French, O.F.; Harris, K.,(1965) Consumptive use of water by crops in Arizona. Tucson: The University of Arizona, Agricultural Experiment Station Technical Bulletin No. 169. 1965. 46p

Fox, A.F.; Scherer, T.; Slack, D.C.; Clark, L.J. AZSCHED-(1992) Arizona irrigation scheduling: user's manual v. 1.01. Tucson, Agricultural and Biosystems Engineering Department, The University of Arizona, 1992. 36p

Grattan, S.R.; Bowers, W.; Dong, A.; Snyder, R.L.; Carroll, J.J.; George, W.(1998) New crop coefficients estimate water use of 
vegetables, row crops. California Agriculture, Berkeley, v.52, n.1, p.16-21, 1998

Gallardo, M.; Jackson, L.E.; Schulbach, K.; Snyder, R.L.; Thompson, R.B.; Wyland, L.J.(1996) Production and water use in lettuces under variable water supply. Irrigation Science, Heidelberg, v.16, p.125-137, 1996

Ghali GS, Svehlik ZJ (1988) Soil-water dynamics and optimum operating regime in trickle irrigated fields. Agric. Water Manage. 13, 127-143.

Irrigation Journal. (2000) Annual irrigation survey continuous steady growth. Irrigation Journal, Heidelberg, v.51, n.1, p.12-41, 2001.]

Lamm,F. R. ;W. E. Spurfeon ; D. H. Roqers and H. L. Manages (1995) Corn production using subsurface drip irrigation proceeding of the fifth international micro irrigation cogress april 2-6, 1995 orland , florida ,USA

Nassar, A.A. and Abou ElAzem ,A. M. (2006 ) Irrigation technologies for improving salt distribution ,pea production and water relations .The 14 annul conference of the miser society of Agr . Eng, 22 Nov 2006

Silber A, Xu G, Wallach R (2003) High irrigation frequency: the effect on plant growth and on uptake of water and nutrients. In Fertilization strategies for field vegetable production. (Ed. NTremblay) Acta Horticulturae 627, 89-96

Stivers, L.J., L.E. Jackson, and G.S. Pettygrove. (1993.) Use of nitrogen by lettuce, celery, broccoli, and cauliflower: A literature review. Calif. Dept. of Food and Agric., Sacramento, CA.

Thomas L. Thompson ,a, Thomas A. Doerge and Ronald E. Godin (2002) Subsurface Drip Irrigation and Fertigation of Broccoli . Soil Science Society of America Journal 66:186-192 (2002

Titley M (2000) Australian lettuce production and processing-An overview. Proc. Of Australian lettuce industry conference, 6-8 June, NSW, Australia. 


\section{الملخص العربيى \\ تأثير نظم الري على محصول الخس البلاي

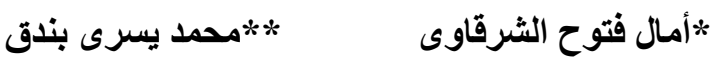

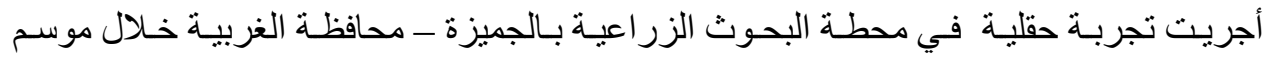

$r \cdot 1 \cdot / r \ldots q$

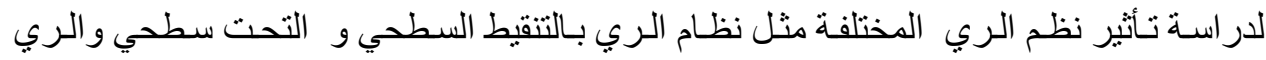

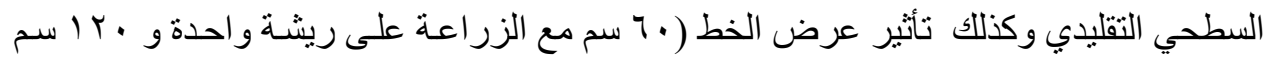

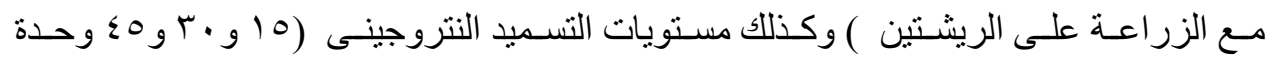

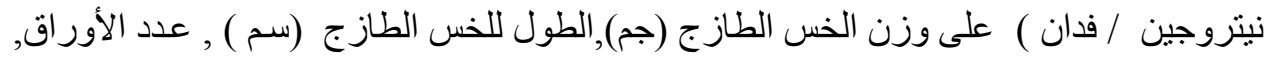

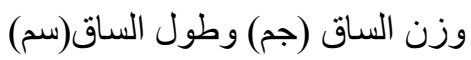

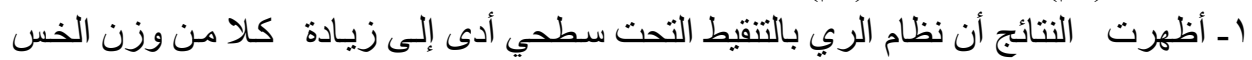

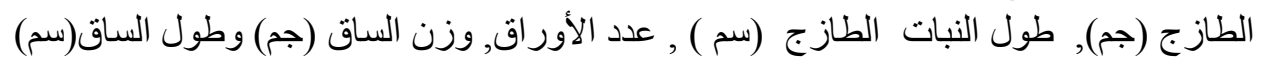
بنســ

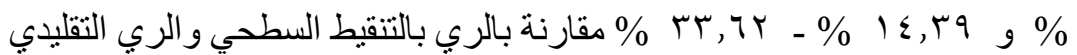

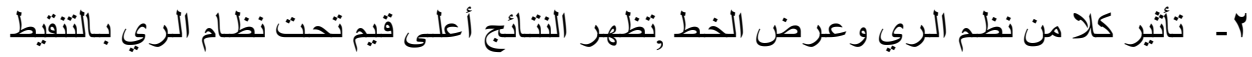

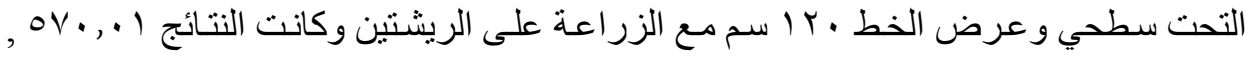

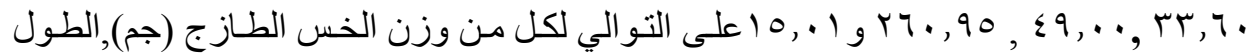

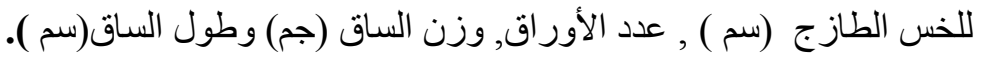

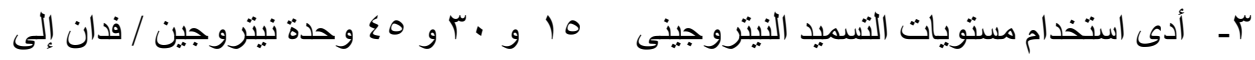

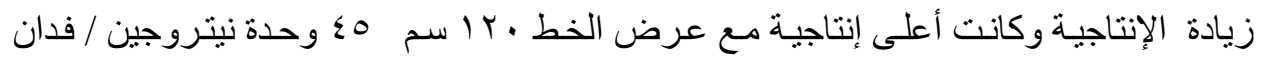

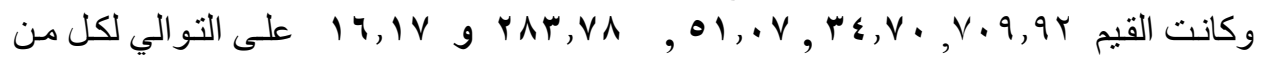

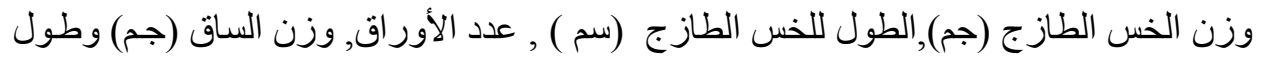

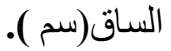

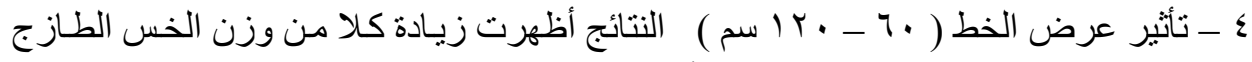

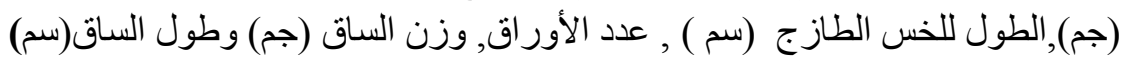

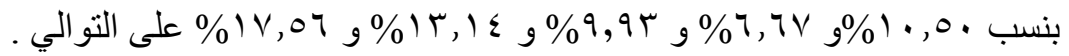

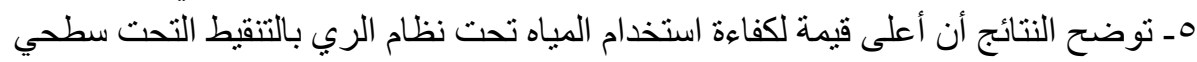

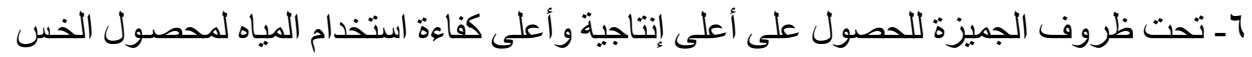

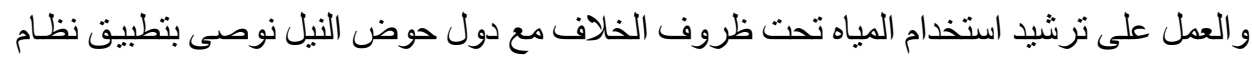

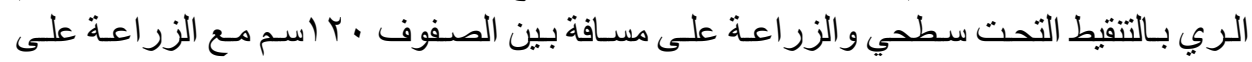
الريشتين والتسميد 0؛ وحدة نيتروجين / فدان.

* باحث أول بمعهد بحوث الهندسة الزر اعية. | باحث بمعهد بحوث الهندسة الزر اعية. 